\title{
Spastic paraplegia-precocious puberty syndrome
}

INSERM

\section{Source}

INSERM. (1999). Orphanet: an online rare disease and orphan drug data base. Spastic paraplegia-precocious puberty syndrome. ORPHA:2826

Spastic paraplegia-precocious puberty syndrome is a complex form of hereditary spastic paraplegia characterized by the onset of progressive spastic paraplegia associated with precocious puberty (due to Leydig cell hyperplasia) in childhood (at the age of 2 years). Moderate intellectual disability was also reported. There have been no further descriptions in the literature since 1983. 